\title{
Role for Laparoscopic Adrenalectomy in Patients with Cushing's Syndrome
}

\begin{abstract}
Laparoscopic adrenalectomy is one of the most clinically important advances in the past 2 decades for the treatment of adrenal disorders. When compared to open adrenalectomy, laparoscopic adrenalectomy is equally safe, effective, and curative; it is more successful in shortening hospitalization and convalescence and has less long-term morbidity. The laparoscopic approach to the adrenal is the procedure of choice for the surgical management of cortisol-producing adenomas and for patients with corticotropin (ACTH) dependent Cushing's syndrome for whom surgery failed to remove the source of ACTH. The keys to successful laparoscopic adrenalectomy are appropriate patient selection, knowledge of anatomy, delicate tissue handling, meticulous hemostasis, and experience with the technique of laparoscopic adrenalectomy. (Arq Bras Endocrinol Metab 2007;51/8:1349-1354)
\end{abstract}

Keywords: Adrenalectomy; Cushing's syndrome; Laparoscopic surgeries

\section{RESUMO}

\begin{abstract}
Papel da Adrenalectomia Laparoscópica em Pacientes com Síndrome de Cushing.

A adrenalectomia laparoscópica é um dos avanços clínicos mais importantes das últimas duas décadas para o tratamento de doenças adrenais. Quando comparada à adrenalectomia aberta (convencional), a adrenalectomia laparoscópica é igualmente segura, efetiva e curativa; ela tem maior sucesso em encurtar a hospitalização e a convalescença e apresenta menor morbidade a longo prazo. A abordagem laparoscópica da adrenal é o procedimento de escolha para ao manejo cirúrgico dos adenomas produtores de cortisol e para os pacientes com síndrome de Cushing ACTH-dependente nos quais a cirurgia hipofisária falhou em remover a fonte de ACTH. Os pontos críticos para o sucesso da adrenalectomia laparoscópica são: a seleção apropriada do paciente, o conhecimento da anatomia da região, o manuseio cuidadoso do tecido, a homeostase meticulosa e a experiência com essa técnica cirúrgica. (Arq Bras Endocrinol Metab 2007;51/8:1349-1354)
\end{abstract}

Descritores: Adrenalectomia; Síndrome de Cushing; Cirurgia laparoscópica

$\mathrm{T}$ HE LAPAROSCOPIC APPROACH to removing the adrenal gland was first reported in $1992(1,2)$ and it has rapidly become the procedure of choice for unilateral adrenalectomy when the adrenal mass is less than $8 \mathrm{~cm}$ in size and there are imaging findings to suggest malignancy (e.g. invasion of contiguous structures) (3). When compared to open adrenalectomy, the laparoscopic approach is associated with shorter postoperative recovery time and less long-term morbidity (3).

\section{atualização}

WILLIAM F. YOUNG, JR. GEOFFREY B. THOMPSON

Divisions of Endocrinology, Diabetes, Metabolism, Nutrition and Internal Medicine (WFY) and the Division of Gastroenterologic and General Surgery (GBT), Mayo Clinic, Rochester, Minnesota, USA.
Recebido em 30/09/07

Aceito em 06/10/07 
In a review of 2,550 laparoscopic adrenalectomy procedures reported in the literature, the most frequent adrenal disorder operated laparoscopically was aldosterone-producing adenoma $(36.2 \%)$ followed by cortisol-producing adenoma (19.1\%), apparent nonfunctioning cortical adenoma (18.2\%), and pheochromocytoma (18.0\%) (3). However, patients with corticotropin (ACTH) dependent Cushing's syndrome who have experienced failed attempts to remove the ACTH-secreting neoplasm (pituitary or ectopic) are also ideal candidates for one-stage bilateral laparoscopic adrenalectomy (4-6). The types of Cushing's syndrome that can be treated with laparoscopic unilateral or bilateral adrenalectomy are summarized in table 1 .

\section{ADVANTAGES OF THE LAPAROSCOPIC APPROACH}

The surgical approach to adrenal was revolutionized with the introduction of the laparoscope. Although laparoscopic adrenalectomy is technically more demanding to perform than conventional open posterior adrenalectomy, it is associated with shorter hospitalization, less morbidity, and earlier return to daily activities (3,6,7,8-12). Conventional open adrenalectomy - by the anterior or posterior approach — requires a large incision to gain access to a relatively small gland. In addition, the incision used for posterior adrenalectomy, with its associated twelfth rib resection and subcostal nerve retraction, has been associated with incisional and musculoskeletal problems that may persist long after the operation $(6,13)$. These incisional problems are especially pronounced and severe in patients with Cushing's syndrome because of poor wound heal-

Table 1. Types of Cushing's syndrome that may be treated laparoscopically.

\begin{tabular}{l}
\hline Unilateral adrenalectomy \\
Cortisol-producing adenoma \\
Bilateral partial adrenalectomy \\
Bilateral cortisol-secreting adenomas \\
Asymmetric ACTH-independent macronodular \\
$\quad$ adrenal hyperplasia (AIMAH) \\
Bilateral adrenalectomy \\
ACTH-independent Cushing's syndrome caused by primary \\
pigmented nodular adrenal disease (PPNAD) or AIMAH \\
ACTH-dependent Cushing's syndrome that failed attempts \\
at removal of ACTH-secreting tumor (pituitary or ectopic) \\
\hline ACTH: corticotropin, AIMAH: ACTH-independent \\
macronodular adrenal hyperplasia, PPNAD: primary \\
pigmented nodular adrenal disease.
\end{tabular}

ing, laxity of the abdominal wall, and obesity associated with the condition (14-17). An abdominal CT scan of an adrenal cortical adenoma in a typical patient with Cushing's syndrome treated with unilateral laparoscopic adrenalectomy is shown in figure 1 .

\section{Bilateral laparoscopic adrenalectomy}

Bilateral laparoscopic adrenalectomy is an excellent treatment option for patients with ACTH-dependent Cushing's syndrome after failed pituitary surgery or when the ACTH source cannot be resected or localized in patients with ectopic ACTH syndrome $(5,18,19)$. Bilateral laparoscopic subtotal adrenalectomy is indicated in patients with bilateral cortisolsecreting adenomas (20). When compared to the open approach, bilateral laparoscopic adrenal surgery is associated with much less tissue injury in patients who are immunocompromised and/or are predisposed to delayed wound healing. An additional advantage because of the magnification - is better visibility of the surgical field, thus decreasing the risk for retained remnants and adrenal rest tissue.

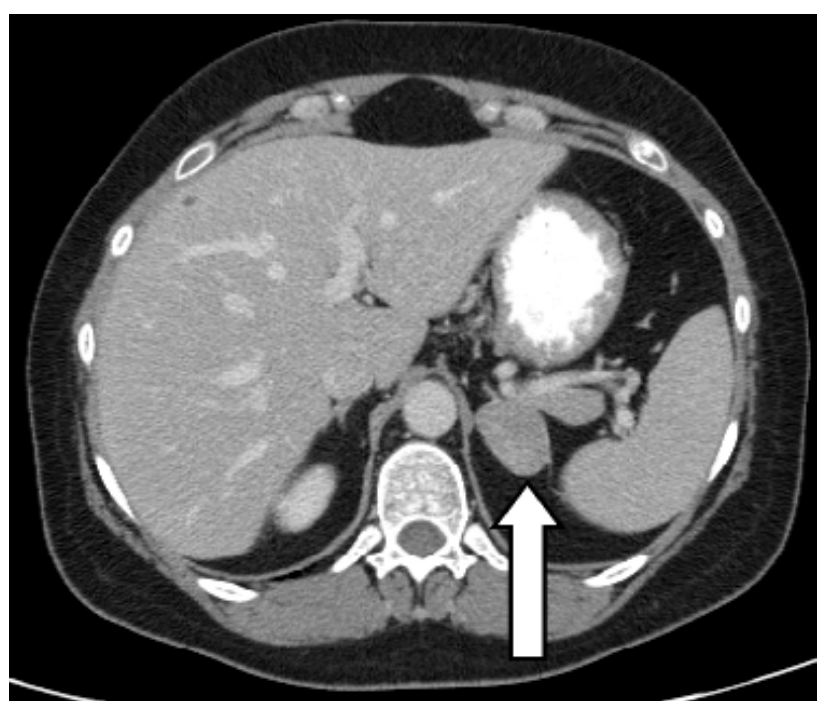

Figure 1. Abdominal CT scan from a 36-year-old woman that presented with hypertension, $14 \mathrm{~kg}$ weight gain, easy bruising, proximal muscle weakness, and poor wound healing. Laboratory studies showed elevated serum cortisol concentrations that lacked diurnal variation, undetectable serum ACTH, increased level of 24-hr urinary free cortisol $(241 \mathrm{mcg}$; normal $=5$ to $55 \mathrm{mcg}$ ). CT scan of the adrenal glands showed a $3.4 \times 2.5 \mathrm{~cm}$ left adrenal mass (arrow). At laparoscopic left adrenalectomy a $3.5 \times 3.0 \times 2.5 \mathrm{~cm}$ cortical adenoma was found. Two days after surgery the serum cortisol concentration was undetectable. The patient was dismissed from the hospital on the second postoperative day on temporary glucocorticoid replacement, and her signs and symptoms of Cushing's syndrome slowly resolved. 
Although transsphenoidal surgery for resection of an ACTH-secreting pituitary tumor is the treatment of choice in patients with pituitary-dependent disease, this surgery is not always successful (21-23) because the pituitary adenoma may invade areas that are not surgically accessible (e.g., cavernous sinuses). Other corticotrope adenomas may be so small that they escape detection and resection at the time of pituitary surgery. Thus, transsphenoidal surgery for pituitarydependent Cushing's syndrome is associated with a $20 \%$ to $40 \%$ failure rate (24-27). Because reoperation in these patients carries an increased risk of causing panhypopituitarism, bilateral adrenalectomy has an important therapeutic role in this setting.

Radiation therapy to the sella is not an optimal therapy for Cushing's disease because its onset of action is slow and the failure rate is unacceptably high (28). The main side effect is some degree of pituitary insufficiency (29). Because bilateral laparoscopic adrenalectomy results in immediate cure of hypercortisolism, the role of pituitary irradiation should be limited to those that demonstrate pituitary tumor growth following bilateral adrenalectomy (Nelson's syndrome) - in this setting sellar radiation therapy or gamma knife radiosurgery are used to prevent a locally invasive pituitary tumor from further encroaching on surrounding structures. However, the clinician should recognize that a fear of Nelson's syndrome should never dissuade proceeding with a definitive cure for Cushing's syndrome.

Patients with the syndrome of ectopic ACTH secretion often have an unresectable or occult source of ACTH secretion $(30,31)$. In these patients, the metabolic manifestations of cortisol excess may appear suddenly and progress rapidly. However, most patients with clinically evident ectopic ACTH syndrome have more indolent tumors, such as bronchial or thymic carcinoid tumors, islet cell tumors, or medullary carcinoma of the thyroid (31). Carcinoid tumors that secrete ACTH may not be apparent even with careful radiological investigation and may take up to 20 years to localize (31). When the source of ACTH is unresectable or occult, bilateral laparoscopic adrenalectomy is a life-saving treatment option because of the minimal morbidity associated with the procedure, especially when compared with conventional adrenalectomy $(5,18,19)$. Laparoscopic adrenalectomy is also superior to medical therapy in regard to tolerance, efficacy, and safety (19). Bilateral laparoscopic adrenalectomy offers improved quality of life and palliation of hypercortisolism-related symptoms even in patients with disseminated, untreatable malignancy (18).
Long-term medical management of Cushing's syndrome is not an optimal treatment option. The adrenal enzyme inhibitors, aminogluthetimide, metyrapone, mitotane, and ketoconazole, are the pharmaceuticals used most often to treat Cushing's syndrome medically. However, complete blockade of adrenal steroid synthesis is typically achieved only transiently; ACTH levels usually increase and override the blockade - leading to additional increases in the dosage of the enzyme inhibitor. The frequency of patient intolerance and side effects (e.g. liver enzyme abnormalities) of these medications is high and few patients are able to tolerate long-term therapy with aminogluthetimide, metyrapone, mitotane, or ketoconazole.

Since the description of laparoscopic adrenalectomy in $1992(1,2)$, multiple centers have described their experience with bilateral laparoscopic adrenalectomy for the treatment of Cushing's syndrome $(3-5,32$ $37)$. Increased experience with the technique has resulted in a decreased conversion rate to open adrenalectomy as well as decreased complications. At our center - between January of 1995 and October of 2006 - bilateral laparoscopic adrenalectomy was attempted in 68 patients with ACTH-dependent Cushing's syndrome (26, ectopic ACTH syndrome; 42, persistent pituitary-dependent Cushing's syndrome following pituitary surgery) and was successfully completed in 59 of 68 patients $(87 \%) ; 9(13 \%)$ required conversion to open adrenalectomy (5). Intra-operative complications occurred in 3 patients (4.4\%) and non-operative complications occurred in 11 (16\%) patients. There were no perioperative deaths. In patients with follow up data available, all achieved biochemical resolution and at least partial clinical resolution of signs and symptoms associated with hypercortisolism. Resolution of hypertension, diabetes, and obesity was achieved in 64\%, $29 \%$, and $35 \%$ of patients carrying those diagnoses prior to surgery, respectively (5).

\section{CONTRAINDICATIONS TO LAPAROSCOPIC ADRENALECTOMY IN THE CUSHING'S SYNDROME PATIENT}

There are at least 3 situations when the laparoscopic approach to the adrenal may not or should not be the procedure of choice for patients with Cushing's syndrome. For example, adrenocortical carcinomas that invade surrounding structures should be resected en bloc by an open anterior abdominal incision. In addition, very large tumors (e.g., $>10-12 \mathrm{~cm}$ in diameter) may be difficult to remove laparoscopically. The risk of 
adrenocortical carcinoma increases proportionate to size as does the risk of capsular invasion. Finally, malignant ACTH-secreting pheochromocytoma especially if lymphadenopathy is found on computerized imaging — should be resected en bloc by an open anterior abdominal incision.

\section{Surgical approaches to the adrenal gland}

In the past, the open posterior retroperitoneal approach was favored by many adrenal surgeons because, when compared to the open anterior approach, it resulted in less pain, ileus, and other complications (39). For laparoscopic adrenalectomy, the lateral transabdominal approach is preferred by most surgeons - the lateral decubitus position of the patient and the medial rotation of the viscera allow gravity to keep the liver, bowel, and spleen away from the surgical field. The posterior retroperitoneoscopic approach to the adrenal has not been found to be superior to the lateral transabdominal approach. However, this approach may be indicated in patients who have had prior upper abdominal surgery. Some surgeons prefer the posterior retroperitoneoscopic approach because of shorter operating time, reduced blood loss, reduced risk of injury to the viscera, and lack of interference from previous abdominal surgery (42). Regardless of the approach, the keys to successful adrenalectomy are knowledge of the anatomy, delicate tissue handling, and meticulous hemostasis. Since clinical outcomes are similar amongst the different approaches for endoscope-based adrenalectomy (42), the choice of the approach is dependent upon surgeon preference and the clinical scenario.

\section{Laparoscopic technique}

General endotracheal anesthesia is used. The patient is placed in the lateral decubitus position with the affected adrenal gland placed in the upper position. The operating table placed in the flexed position so that the patient's flank is maximally exposed in the extended position. The initial skin incision $-1-\mathrm{cm}$ in length - is $2 \mathrm{~cm}$ below and parallel to the costal margin and the pneumoperitoneum is established with carbon dioxide. Then the surgeon places 3 to $410-\mathrm{mm}$ trocar ports - the laparoscope is initially placed through the most anterior trocar and working instruments through the other ports (camera and instruments are interchangeable throughout the dissection). The right adrenal gland approach involves: mobilization of the lateral attachments of the liver for medial rotation and elevation; inferior retraction of the kidney; exposure of adrenal vein and vena cava. The left adrenal gland approach involves: mobilization of the left colon along its attachments to the spleen; mobilization of the spleen and pancreas to allow a medial position; exposure of left adrenal vein/inferior phrenic vein junction; and mobilization of the adrenal gland along Gerota's fascia. For both the right and left adrenal glands, the main adrenal is vein identified, clipped and transected; the adrenal gland and tumor are resected and placed in a retrieval pouch and delivered via a port site. The adrenal vein may be transected early or late in the dissection depending on the ease of exposure.

Most patients begin a clear liquid diet the evening of surgery and a regular diet the next day. Patients are encouraged to ambulate the evening of surgery. Most patients undergoing unilateral adrenalectomy may be dismissed from the hospital on postoperative day 1 or 2. Bilateral adrenalectomy patients and patients with severe Cushing's syndrome may require more than a 2 -day hospitalization.

\section{Efficacy of laparoscopic adrenalectomy}

Prospective human randomized controlled trials comparing laparoscopic adrenalectomy to any of the open surgical approaches has not and will not be done (3). In a prospective randomized study done at the Mayo Clinic, we examined the acute-phase response and wound healing in laparoscopic adrenalectomy versus open adrenalectomy in a cushingoid porcine model (17). Nitrogen balance, wound scores, and tensile strength at 24 hours and 1 week were more favorable in the laparoscopic adrenalectomy group than the open adrenalectomy group. At least 20 case-control retrospective comparative studies in humans have evaluated the efficacy of laparoscopic adrenalectomy (3). All of the studies reported less analgesia requirement, less blood loss, lower complication rate, and shorter hospital stay for laparoscopic than open adrenalectomy (3). At Mayo Clinic, we performed a matched casecontrol study comparing 50 patients having laparoscopic adrenalectomy to 50 patients having adrenalectomy through the open posterior approach (6). We found that laparoscopic adrenalectomy, compared to open adrenalectomy, was associated with shorter hospital stay, less postoperative narcotic use, more rapid return to normal activity, increased patient satisfaction, and less late morbidity. The late morbidity associated with posterior open adrenalectomy includes chronic pain, marked laxity involving the oblique muscles, and bothersome flank numbness (6). The average conversion rate from laparoscopic to open adrenalectomy in a total of 2,550 patients from 28 reports was 3.6\% (3). The reasons for conversion included bleeding, adhe- 
sions, difficulty of dissection, unexpected malignancy, large size of tumor, vascular invasion, inadvertent pancreatic injury, damage to the pleura, failure to identify the adrenal tumor, and unsuspected Bochdalek hernia $(6,43-46)$.

\section{Risks of laparoscopic adrenalectomy}

The surgeon sacrifices some tactile sensation, when compared to open surgery, and the small, flat, friable adrenal gland is manipulated with instruments in a 2dimensional plane. The overall complication rate associated with laparoscopic adrenalectomy from a summary of 2,550 procedures was $9.5 \%$ (3). Some complications of laparoscopic adrenalectomy include conversion to open adrenalectomy, bleeding, gland fragmentation, wound hematomas, organ injury, port site incisional hernia (47), and port site pain (48). Nerve root pain has been reported with the posterior laparoscopic adrenalectomy approach (42). There is risk of violating the tumor capsule and organ parenchyma during manipulation with the laparoscopic instruments. In one series involving 88 patients (43) there was a $12 \%$ postoperative complication rate (e.g., deep venous thrombosis, hematomas, anemia), a $3 \%$ conversion rate to open adrenalectomy, and no mortality. In a series of 560 adrenalectomies by the posterior retroperitoneoscopic approach the mortality was zero; conversions to open or laparoscopic lateral surgery were necessary in 9 patients (1.7\%); major complications occurred in $1.3 \%$ of patients; minor complications in $14.4 \%(40)$.

In patients with ACTH-dependent Cushing's syndrome, any viable cortical cells left behind in the patient will result in persistent/recurrent hypercortisolism (4). Recurrent adrenocortical carcinoma following laparoscopic adrenalectomy has been reported $(49,50)$; it is not known if the laparoscopic adrenalectomy approach is related to the recurrent disease. An additional concern about laparoscopic adrenalectomy for malignant adrenal disease is tumor seeding at the level of the port incision.

The mortality rate for 2,550 laparoscopic adrenalectomies was $0.2 \%(3) ; 4$ of the 7 deaths occurred in patients with Cushing's disease who underwent bilateral laparoscopic adrenalectomy (3).

\section{SUMMARY}

Laparoscopic adrenalectomy is safe, effective, curative, and shortens hospitalization and convalescence. Laparoscopic adrenalectomy is the procedure of choice for the surgical management of Cushing's syndrome patients that have cortisol-producing adenomas (unilateral or bilateral), ACTH-dependent Cushing's syndrome and failed surgery for the removal of the source of ACTH, bilateral primary pigmented nodular adrenal disease, and ACTH-independent bilateral adrenal macronodular hyperplasia. Contraindications for laparoscopic adrenalectomy include adrenocortical carcinomas, very large tumors (e.g., > 10-cm in diameter), and patients with malignant $\mathrm{ACTH}$-secreting pheochromocytomas. The keys to successful laparoscopic adrenalectomy are appropriate patient selection, knowledge of anatomy, delicate tissue handling, meticulous hemostasis, and experience with advanced laparoscopic surgery.

\section{REFERENCES}

1. Gagner M, Lacroix A, Bolte E. Laparoscopic adrenalectomy in Cushings syndrome and pheochromocytoma [Letter]. N Engl J Med 1992;327:1033.

2. Higashihara E, Tanaka Y, Horie S, Aruga S, Nutahara K, Homma $Y$, et al. A case report of laparoscopic adrenalectomy. Nippon Hinyokika Gakkai Zassh 1992;83:1130-3.

3. Assalia A, Gagner M. Laparoscopic adrenalectomy. Br J Surg 2004:91:1259-74.

4. Chapuis $Y$, Chastanet S, Dousset B, Luton J-P. Bilateral laparoscopic adrenalectomy for Cushing's disease. Br J Surg 1997;84:1009.

5. Chow JT, Thompson GB, Grant CS, Farley DR, Richards ML, Young WF Jr. Bilateral laparoscopic adrenalectomy for corticotropin-dependent Cushing's Syndrome: A review of the Mayo Clinic experience. Clin Endocrinol 2007; in press.

6. Thompson GB, Grant CS, van Heerden JA, Schlinkert RT, Young WF Jr, Farley DR, et al. Laparoscopic versus open posterior adrenalectomy: A case-control study of 100 patients. Surgery 1997;122:1132-6.

7. Korman JE, Ho T, Hiatt JR, Phillips EH. Comparison of laparoscopic and open adrenalectomy. Am Surg 1997;63:908-12.

8. Guazzoni G, Montorsi F, Bocciardi A, Da Pozzo L, Rigatti P, Lanzi $R$, et al. Transperitoneal laparoscopic versus open adrenalectomy for benign hyperfunctioning adrenal tumors: A comparative study. J Urol 1995;153:1597-600.

9. Prinz RA. A comparison of laparoscopic and open adrenalectomies. Arch Surg 1995;130:489-94.

10. MacGillivray DC, Shichman SJ, Ferrer FA, Malchoff CD. A comparison of open vs laparoscopic adrenalectomy. Surg Endoscopy 1996;10:987-90.

11. Hansen $P, B a x T$, Swanstrom L. Laparoscopic adrenalectomy: history, indications, and current techniques for a minimally invasive approach to adrenal pathology. Endoscopy 1997; 29:309-14.

12. Horgan S, Sinanan M, Helton WS, Pellegrini CA. Use of laparoscopic techniques improves outcome from adrenalectomy. Am J Surg 1997;173:371-4.

13. Buell JF, Alexander HR, Norton JA, Yu KC, Fraker DL. Bilateral adrenalectomy for Cushing's syndrome. Anterior versus posterior surgical approach. Ann Surg 1997;225:63-8.

14. van Heerden JA, Young Jr WF, Grant CS, Carpenter PC. Adrenal surgery for hypercortisolism: surgical aspects. Surgery 1995;117:466-72.

15. Watson RG, van Heerden JA, Northcutt RC, Grant CS, Ilstrup DM. Results of adrenal surgery for Cushings syndrome: 10 years experience. World J Surg 1986;10:531-8. 
16. O'Riordain DS, Farley DR, Young Jr WF, Grant CS, van Heerden JA. Long-term outcome of bilateral adrenalectomy in patients with Cushings syndrome. Surgery 1994; 116:1088-93.

17. Kollmorgen CF, Thompson GB, Grant CS, van Heerden JA, Byrne J, Davies ET, et al. Laparoscopic versus open posterior adrenalectomy: Comparison of acute-phase response and wound healing in the cushingoid porcine model. World J Surg 1998;22:613-20.

18. Thompson SK, Hayman AV, Ludlam WH, Deveney CW, Loriaux DL, Sheppard BC. Improved quality of life after bilateral laparoscopic adrenalectomy for Cushing's disease: a 10-year experience. Ann Surg 2007;245:790-4.

19. Mikhail AA, Tolhurst SR, Orvieto MA, Stockton BR, Zorn KC, Weiss $R E$, et al. Open versus laparoscopic simultaneous bilateral adrenalectomy. Urology 2006;67:693-6.

20. Young WF Jr, du Plessis H, Thompson GB, Grant CS, Farley $\mathrm{DR}$, Richards $\mathrm{ML}$, et al. The clinical conundrum of corticotropin-independent autonomous cortisol secretion in patients with bilateral adrenal masses. World J Surg 2008; in press.

21. Swearingen B, Biller BM, Barker FG, Katznelson L, Grinspoon $\mathrm{S}$, Klibanski $\mathrm{A}$, et al. Long-term mortality after transsphenoidal surgery for Cushing disease. Ann Intern Med 1999; 130:821-4.

22. Mampalam TJ, Tyrrell JB, Wilson CB. Transsphenoidal microsurgery for Cushing disease: a report of 216 cases. Ann Intern Med 1988; 109:487-93.

23. Chee GH, Mathias DB, James RA, Kendall-Taylor P. Transsphenoidal pituitary surgery in Cushing's disease: can we predict outcome? Clin Endocrinol (Oxf) 2001:54:617-26.

24. Invitti C, Giraldi FP, de Martin M, Cavagnini F. Diagnosis and management of Cushings syndrome: results of an Italian multicentre study. Study Group of the Italian Society of Endocrinology on the Pathophysiology of the HypothalamicPituitary-Adrenal Axis. J Clin Endocrinol Metab 1999; 84:440-8.

25. McCance DR, Russell CF, Kennedy TL, Hadden DR, Kennedy $\mathrm{L}$, Atkinson AB. Bilateral adrenalectomy: low mortality and morbidity in Cushings disease. Clin Endocrinol (Oxf) 1993;39:315-21.

26. Tahir $A H$, Sheeler LR. Recurrent Cushing s disease after transsphenoidal surgery. Arch Intern Med 1992;152:977-81.

27. Toms GC, McCarthy MI, Niven MJ, Orteu CH, King TT, Monson JP. Predicting relapse after transsphenoidal surgery for Cushings disease. J Clin Endocrinol Metab 1993;76:291-4.

28. Orth DN, Liddle GW. Results of treatment in 108 patients with Cushings syndrome. N Engl J Med 1972;285:243-7.

29. Estrada J, Boronat M, Mielgo M, Magallon R, Millan I, Diez S, et al. The long-term outcome of pituitary irradiation after unsuccessful transsphenoidal surgery in Cushings disease. $\mathbf{N}$ Engl J Med 1997;336:172-7.

30. Limper AH, Carpenter PC, Scheithauer B, Staats BA. The Cushing syndrome induced by bronchial carcinoid tumors. Ann Intern Med 1992;117:209-14.

31. Aniszewski JP, Young, WF Jr, Thompson GB, Grant CS, van Heerden JA. Cushing syndrome due to ectopic adrenocorticotropic hormone secretion. World J Surg 2001:25;934-40.

32. Chapuis Y. Laparoscopic versus Young-Mayor open posterior adrenalectomy: a case-control study of 100 patients. Chirurgie 1998;123:322-3.

33. Chapuis Y, Pitre J, Conti F, Abboud B, Pras-Jude N, Luton JP. Role and operative risk of bilateral adrenalectomy in hypercortisolism. World J Surg 1996;20:775-9.

34. Ferrer FA, MacGillivray DC, Malchoff CD, Albala DM, Shichman SJ. Bilateral laparoscopic adrenalectomy for adrenocorticotropic dependent Cushing's syndrome. J Urol 1997;157:16-8.

35. Bax TW, Marcus DR, Galloway GO, Swanstrom LL, Sheppard BC. Laparoscopic bilateral adrenalectomy following failed hypophysectomy. Surg Endosc 1996;10:1150-3.
36. Lanzi R, Montorsi F, Losa M, Centemero A, Manzoni MF, Rigatti $\mathrm{P}$, et al. Laparoscopic bilateral adrenalectomy for persistent Cushing's disease after transsphenoidal surgery. Surgery 1998; $123: 144-50$.

37. Acosta E, Pantoja JP, Famino R, Rull JA, Herrera MF. Laparoscopic versus open adrenalectomy in Cushing's syndrome and disease. Surgery 1999;126:1111-6.

38. Hawn MT, Cook D, Deveney C, Sheppard BC. Quality of life after laparoscopic bilateral adrenalectomy for Cushing's disease. Surgery 2002;132:1064-9.

39. Proye CA, Huart JY, Cuvillier XD, Assez NM, Gambardella B, Carnaille BM. Safety of the posterior approach in adrenal surgery: Experience in 105 cases. Surgery 1993; 114:1126-31.

40. Walz MK, Alesina PF, Wenger FA, Deligiannis A, Szuczik E, Petersenn S, et al. Posterior retroperitoneoscopic adrenalectomy - results of 560 procedures in 520 patients. Surgery 2006; 140:943-50.

41. Miyake O, Yoshimura K, Yoshioka T, Honda M, Kokado Y, Miki T, et al. Laparoscopic adrenalectomy. Comparison of the transperitoneal and retroperitoneal approach. Eur Urol 1998;33:303-7.

42. Duh QY, Siperstein AE, Clark OH, Schecter WP, Horn JK, Harrison MR, et al. Laparoscopic adrenalectomy. Comparison of the lateral and posterior approaches. Arch Surg 1996;131:870-6.

43. Gagner M, Pomp A, Haeniford BT, Pharand D, Lacroix A. Laparoscopic adrenalectomy: Lessons learned from 100 consecutive procedures. Ann Surg 1997;226:238-47.

44. Higashihara E, Baba S, Nakagawa K, Murai M, Go H, Takeda $M$, et al. Learning curve and conversion to open surgery in cases of laparoscopic adrenalectomy and nephrectomy. J Urol 1998;159:650-3.

45. Bonjer HJ, Lange JF, Kazemier G, de Herder WW, Steyerberg EW, Bruining HA. Comparison of three techniques for adrenalectomy. Br J Surg 1997;84:679-82.

46. Shen WT, Kebebew E, Clark OH, Duh Q-Y. Reasons for conversion from laparoscopic to open or hand-assisted adrenalectomy: Review of 261 laparoscopic adrenalectomies from 1993 to 2003. World J Surg 2004.

47. Rutherford JC, Stowasser M, Tunny TJ, Klemm SA, Gordon RD. Laparoscopic adrenalectomy. World J Surg 1996; 20:758-61.

48. Vargas HI, Kavoussi LR, Bartlett DL, Wagner JR, Venzon DJ, Fraker DL, et al. Laparoscopic adrenalectomy: A new standard of care. Urology 1997;49:673-8.

49. Hofle G, Gasser RW, Lhotta K, Janetschek G, Kreczy A, Finkenstedt G. Adrenocortical carcinoma evolving after diagnosis of preclinical Cushing's syndrome in an adrenal incidentaloma. A case report. Horm Res 1998;50:237-42.

50. Hamoir E, Meurisse M, Defechereux T. Is Iaparoscopic resection of a malignant corticoadrenaloma feasible? Report of a case of early, diffuse and massive peritoneal recurrence after attempted laparoscopic resection. Ann Chir 1998;52:364-8.

\section{Address for correspondence:}

William F. Young, Jr.

Division of Endocrinology, Diabetes, Metabolism, Nutrition and Internal Medicine

Mayo Clinic Rochester

200 First Street S.W., Rochester

MN 55905

Fax: 507-284-5745

E-mail: young.william@mayo.edu 